\title{
Growing Pereskia aculeata under intermittent irrigation according to levels of matric potential reduction ${ }^{1}$
}

\author{
Carla Regina Amorim dos Anjos Queiroz ${ }^{2}$, Reginaldo Rodrigues de Andrade ${ }^{2}$, \\ Sérgio Antônio Lemos de Morais ${ }^{3}$, Luiz Carlos Pavani ${ }^{4}$
}

\section{RESUMO}

Cultivo de Pereskia aculeata sob irrigação intermitente de acordo com níveis de redução no potencial mátrico

“Ora-pro-nobis" (Pereskia aculeata Mill.) é uma hortaliça não convencional, no Brasil. Levando-se em conta seu potencial para o cultivo agronômico, objetivou-se avaliar a resposta dessa planta ao défice hídrico intermitente por redução controlada no potencial matricial do substrato, em casa-de-vegetação. Os tratamentos consistiram na aplicação de volumes de água aos vasos, calculados para elevar o potencial mátrico a $-5 \mathrm{kPa}$, com base na curva de retenção de água do substrato, toda vez que a média do potencial mátrico atingisse de $-10 \mathrm{kPa}$ a $-70 \mathrm{kPa}$, dependendo do tratamento. Aos 140 dias após o transplantio, foram avaliadas a área foliar e as massas secas de folhas, caules e raízes. A redução intermitente do potencial mátrico na zona radicular de "Ora-pro-nobis" afetou menos a acumulação de massa seca nas folhas (redução de 21,4\%) do que nos caules (redução de 48,1\%) e nas raízes (redução de 63,7\%), o que é interessante, já que as folhas são o principal produto comercial dessa planta. O tratamento também modificou a proporcionalidade de alocação de massa seca entre as partes da planta e reduziu a eficiência fotossintética das folhas, evidenciada pelo aumento linear da área foliar específica $\left(0,63 \mathrm{~cm}^{2} \mathrm{~g}^{-1} \mathrm{kPa}^{-1}\right)$ e da razão de área foliar $\left(0,39 \mathrm{~cm}^{2} \mathrm{~g}^{-1} \mathrm{kPa}^{-1}\right)$, mas não afetou diretamente a área foliar.

PALAVRAS-CHAVE: Défice hídrico; hortaliça nãoconvencional; "Ora-pro-nobis".

\section{INTRODUCTION}

Pereskia aculeata Mill. is known in Brazil as "Ora-pro-nobis" (Barbados gooseberry, in English), a broad-leaved climber (Duarte \& Hayashi 2005). It is considered a non-conventional vegetable (Brasil 2010), whose leaves are used for human consumption in natura, as in salads, processed, cooked and roasted

\section{ABSTRACT}

Pereskia aculeata Mill., popularly known in Brazil as "Ora-pro-nobis", is an unconventional edible vegetable. Taking into account its potential for agronomic cultivation, this study aimed to evaluate the growth response of this plant under intermittent drought through controlled reductions in the substrate matric potential, in a greenhouse. Treatments consisted of adding to the pots a volume of water to raise the matric potential to $-5 \mathrm{kPa}$, according to the water retention curve in the substrate, whenever the mean substrate matric potential reached values between $-10 \mathrm{kPa}$ and $-70 \mathrm{kPa}$, depending on the treatment. At 140 days after transplanting, leaf area and dry mass of leaves, stems and roots were determined. The intermittent reduction of the matric potential in the root zone of "Ora-pro-nobis" affected less the dry mass accumulation in leaves (reduction of $21.4 \%$ ) than in stems (reduction of $48.1 \%$ ) and roots (reduction of $63.7 \%$ ), and that is interesting because leaves are the main commercial product of this plant. The treatment also modified the proportionality of dry mass allocation among plant parts and reduced the photosynthetic efficiency of leaves, fact evidenced by the linear increase of the specific leaf area $\left(0.63 \mathrm{~cm}^{2} \mathrm{~g}^{-1} \mathrm{kPa}^{-1}\right)$ and leaf area ratio $\left(0.39 \mathrm{~cm}^{-2} \mathrm{~g}^{-1} \mathrm{kPa}^{-1}\right)$, although not affecting directly the leaf area.

KEY-WORDS: Water deficit; unconventional edible vegetable; "Ora-pro-nobis".

(Almeida \& Corrêa 2012), especially due to its high mineral and protein contents (Takeit et al. 2009).

Scientific studies on growth characteristics and agronomic management of this species are still scarce. Leuenberger (1992) reports general aspects of Pereskia species growth and Toffaneli \& Resende (2011) describe its growth with the aid of trellises.

1. Article received in Nov./2013 and accepted for publication in Dec./2014 (http://dx.doi.org/10.1590/1983-40632015v4527210).

2. Instituto Federal de Educação, Ciência e Tecnologia do Triângulo Mineiro (IFTM), Câmpus Uberlândia, Uberlândia, MG,

Brasil.E-mails: carlaregina@iftm.edu.br, reginaldoandrade@iftm.edu.br.

3. Universidade Federal de Uberlândia (UFU), Instituto de Química, Uberlândia, MG, Brasil. E-mail: salemos@ufu.br. 4. Universidade Estadual Paulista "Júlio de Mesquita Filho" (Unesp), Faculdade de Ciências Agrárias e Veterinárias, Jaboticabal, SP, Brasil.E-mail: pavani.lc@gmail.com. 
Water is an essential production factor in plants and it is considered the most limiting factor for the growth of cultivated plants (Shao et al. 2008). It acts maintaining leaf temperature and as a solvent, carrier of nutrients and a reagent in the photosynthesis reaction. Thus, the water deficit in root zones causes permanent or temporary water stress in plants by interfering with the cells metabolism and photosynthesis process. As a result, drought reduces dry matter accumulation and distribution, especially at the initial phase of plant growth and establishment (Yin et al. 2005, Shao et al. 2008).

Cell inhibition and growth rate are regulated by a complex metabolic process, not just a function of water availability for turgor maintenance (Neumann 2008), differing widely in the capacity to cope with drought (Kozlovski \& Pallardy 2002), as well as sensing drought (Chaves et al. 2002).

Plants subjected to water deficit usually have significant mass reduction, as observed in Myracrodruon urundeuva (Figueirôa et al. 2004), Azadirachta indica (Martins et al. 2010), Erythrina velutina (Silva et al. 2010) and Opuntia cactus (Snyman 2004). Drought also causes higher allocation of photosynthates to roots than shoots (Kozlovski \& Pallardy 2002, Silva \& Nogueira 2003), stomatal closure, leaf growth inhibition, osmostic adjustment (Chaves et al. 2002, Silva et al. 2009 and 2010) and changes in tissue elasticity (Kozlovski \& Pallardy 2002, Tardieu et al. 2011).

Skirycz \& Inzé (2010) emphasize that under abiotic stresses plants actively re-program their growth, recover it and adapt themselves, once stress conditions become stable. These mechanisms of adaptation and stress tolerance are called by Kroon et al. (2005) "plant plasticity", which may be more related to specific parts of plants, as seen in soybean (Stolf et al. 2009) and in Pereskia species (Leuenberger 1992).

Since water movement from soil to plant occurs towards the reduction in the total water potential in this system, the matric potential, measured as a component of the total hydric potential, can be considered as the total potential, if the soil or substrate is neither saturated nor saline, and the measurements are made at the same height reference, so that the gravity potential can be considered the same in all measurements (Reichardt \& Timm 2004).

In commercial and experimental areas in which crop irrigation is based on soil or substrate matric potential, this is usually measured at the root zone with microporous ceramic cup tensiometers (Lopes et al. 2004), like in onion (Vilas Boas et al. 2011), carrots (Lima Júnior et al. 2012) and Tahiti lemon (Coelho et al. 2007). This device is considered an accurate and sensitive instrument for in situ matric potential measurements (Brito et al. 2009).

Since "Ora-pro-nobis" has a potential to become a commercially cultivated plant, and considering that its response to water deficit in the root zone is scarce or inexistent, its accumulated dry mass and leaf area were evaluated during 120 days of plant growth as influenced by intermittent drought through reductions in the substrate matric potential.

\section{MATERIAL AND METHODS}

This was a two-phase experiment conducted in Uberlândia (18 $45^{\prime} \mathrm{S}, 48^{\circ} 17^{\prime} \mathrm{W}$ and mean altitude of $633 \mathrm{~m}$ ), Minas Gerais State, Brazil, from March to July, in 2010.

The first phase, lasting 28 days, was dedicated to obtaining young plants to be later transplanted to pots, in a greenhouse with $50 \%$ of light interception.

Stem cuttings were obtained for producing seedlings without genetic variation that could lead to differences in their natural development. To ensure the greatest homogeneity possible to the initial conditions for plant growth, 300 uniform cuttings with length of $20 \mathrm{~cm}$ and diameter between $8 \mathrm{~mm}$ and $9 \mathrm{~mm}$ were collected from branches of the same mother plant (registered at the Universidade Federal de Uberlândia Herbarium with the number 55,887), which presented white flowers and edible succulent leaves. These cuttings were planted without rooting hormones in plastic containers of $1.0 \mathrm{dm}^{3}$ filled with Bioplant ${ }^{\circledR}$ substrate. Among the most vigorous and uniform plants, 48 seedlings were selected, 28 days after planting, and transplanted to pots (one per pot) and placed in a greenhouse.

Before transplanting, in a procedure parallel to the first stage, forty-eight $11.8 \mathrm{dm}^{3}$ plastic pots $(25.6 \mathrm{~cm}$ of height, $27.8 \mathrm{~cm}$ of top diameter and $20.7 \mathrm{~cm}$ of bottom diameter) were filled with $10.15 \mathrm{dm}^{3}$ of substrate prepared with a $6: 3: 1$ volume mixture of soil removed from the $0-20 \mathrm{~cm}$ deep layer of a typical dystroferric Red Latosol, medium sand and dry cattle manure. The substrate of each pot was mixed in individual plastic bags with lime to raise its 
base saturation (V) to $70 \%$ and with $50 \mathrm{~g}$ of a $4: 14: 8$ $\left(\mathrm{N}: \mathrm{P}_{2} \mathrm{O}_{5}: \mathrm{K}_{2} \mathrm{O}\right)$ granular fertilizer formula. After that, all pots received $3,950 \mathrm{~mL}$ of water to saturate the substrate. Each pot was kept covered for 10 days, with a plastic bag perforated by two small plastic straws through which occurred gas exchange with the air outside the pot.

The physical and chemical composition of the substrate (soil + sand + cow manure) presented $\mathrm{pH}=$ $6.6 ; \mathrm{H}+\mathrm{Al}=2.3 \mathrm{cmol} \mathrm{dm}^{-3} ; \mathrm{Mg}=1.2 \mathrm{cmol}_{\mathrm{c}} \mathrm{dm}^{-3}$; $\mathrm{Ca}=3.3 \mathrm{cmol} \mathrm{dm}^{-3} ; \mathrm{P}=6.6 \mathrm{mg} \mathrm{dm}^{-3}$; and $\mathrm{K}=$ $430 \mathrm{mg} \mathrm{dm}^{-3}$. The effective cation exchange was 5.6; aluminum saturation $0 \%$; and organic matter $2.6 \%$. The substrate bulk density was $1.28 \mathrm{~kg} \mathrm{dm}^{-3}$; $440 \mathrm{~g} \mathrm{~kg}^{-1}$ of clay; $91 \mathrm{~g} \mathrm{~kg}^{-1}$ of silt; $423 \mathrm{~g} \mathrm{~kg}^{-1}$ of coarse sand; and $45 \mathrm{~g} \mathrm{~kg}^{-1}$ of fine sand. For the second stage, there was no artificial control of air temperature, relative humidity or wind.

The second phase took place in a protected environment (inside a greenhouse) and started by potting up the young plants and giving them a total of 20 days to adapt to the new environmental conditions. After that, plants were submitted to the previously established treatments of water potential reduction. This phase lasted 120 days.

Pots were arranged on a $1.0 \mathrm{~m}$ high wooden bench, according to a completely randomized design, with four treatments of substrate matric potential, six replications and two plants per replicate. The four treatments of substrate matric potential reduction were established at intervals of $-20 \mathrm{kPa}$, starting from $-10 \mathrm{kPa}$. Treatments consisted in irrigating pots with a calculated volume of water to raise the matric potential to $-5 \mathrm{kPa}$, every time that, at the average depth of the root zone, the matric potential reached a value around $-10 \mathrm{kPa},-30 \mathrm{kPa},-50 \mathrm{kPa}$ or $-70 \mathrm{kPa}$. In order to have all pots with uniform moisture content after the plant acclimatization period, 2,250 $\mathrm{mL}$ of water were added to each one, enough to saturate the substrate, assuring similar conditions of water content.
The irrigation day of each treatment was defined by daily measurements of the matric potentials of the substrate, in the morning period, with tensiometers installed 17 days after transplantation, at $10 \mathrm{~cm}$ depth (average depth of the substrate in pots), in three pots per treatment. When the average values of matric potential reached a value close to those established for that treatment $(-10 \mathrm{kPa},-30 \mathrm{kPa}$, $-50 \mathrm{kPa}$ or $-70 \mathrm{kPa}$ ), all pots were irrigated to raise the substrate matric potential to $-5 \mathrm{kPa}$ (upper limit). The volume of irrigated water was calculated using the characteristic water retention curve of the substrate obtained by applying the Genuchten (1980) model (Table 1):

$$
\theta=\theta_{\mathrm{r}}+\frac{\left(\theta_{\mathrm{s}}-\theta_{\mathrm{r}}\right)}{\left[1+(\alpha|\psi|)^{\mathrm{n}}\right]^{\mathrm{m}}}
$$

where $\theta$ is the soil moisture as a function of the module of matric potential $(\psi ; \mathrm{kPa})\left(\mathrm{m}^{3} \mathrm{~m}^{-3}\right) ; \theta_{\mathrm{r}}$ is the residual soil moisture $\left(\mathrm{m}^{3} \mathrm{~m}^{-3}\right) ; \theta_{\mathrm{s}}$ is the soil moisture at saturation $\left(\mathrm{m}^{3} \mathrm{~m}^{-3}\right)$; and $\alpha\left(\mathrm{kPa}^{-1}\right), \mathrm{n}$ and $\mathrm{m}$ (dimensionless) are fitting parameters of the model.

The amount of water applied per pot in each irrigation time was calculated according to the following expression:

$$
\mathrm{Vi}=\left(\theta_{-5}-\theta_{\Psi \mathrm{i}}\right) \mathrm{V}_{\mathrm{p}}
$$

where $\mathrm{Vi}$ is the volume of water applied in each irrigation $(\mathrm{L}) ; \theta_{-5}$ is the substrate volumetric moisture for the matric potential of $-5 \mathrm{kPa}\left(\mathrm{m}^{3} \mathrm{~m}^{-3}\right)$; $\theta_{\Psi_{\mathrm{i}}}$ is the soil moisture for the matric potential measured on the irrigation day $\left(\mathrm{m}^{3} \mathrm{~m}^{-3}\right)$; and $\mathrm{V}_{\mathrm{p}}$ is the volume of soil in the pot $\left(\mathrm{dm}^{3}\right)$.

At 120 days after the start of treatments (140 days after transplanting), the plants, still in their vegetative phase of development, were removed from pots to determine the dry mass of roots, stems and leaves, after drying them at $65^{\circ} \mathrm{C}$, for 72 hours, in an oven with forced air circulation.

Table 1. Parameters of the Genuchten (1980) retention curve equation model and substrate moisture calculated for the substrate matric potential related to the treatments and to the upper limit of available water in the substrate (-5 kPa) (Uberlândia, Minas Gerais State, Brazil, 2010).

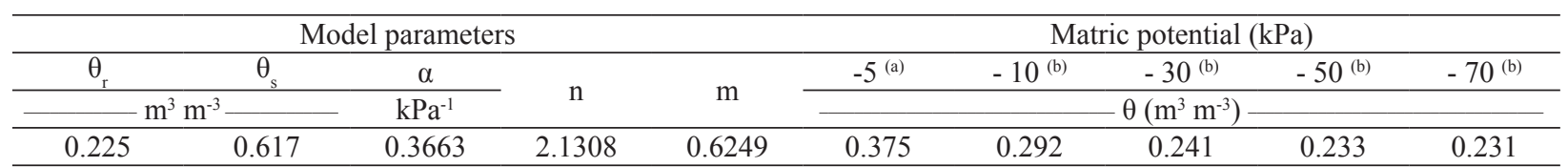

$\theta_{\mathrm{r}}$ : residual substrate moisture; $\theta_{\mathrm{s}}$ : substrate moisture at saturation; $\alpha, \mathrm{n}$ and $\mathrm{m}$ : parameters of the adjusting model; ${ }^{(\mathrm{a})}$ substrate matric potential for which were calculated the volumes of water needed to each treatment; ${ }^{(b)}$ substrate matric potential of each treatment. 
Before drying, from the total number of leaves per plant, 20 were randomly sampled and their images scanned at $100 \mathrm{dpi}$ resolution. These images were processed with the Image $\mathrm{J}$ program to calculate the leaf area (Abramoff et al. 2004). With the dry mass and area of 20 leaves and the total dry mass of leaves, the total plant leaf area was calculated, observing the proportionality between leaf area and dry mass.

With the leaf area (LA) and the accumulated dry mass of leaves (LDM), stems (SDM) and roots (RDM), the accumulated dry mass of shoot $(\mathrm{ShDM}=$ $\mathrm{LDM}+\mathrm{SDM})$ and whole plant $(\mathrm{PDM}=\mathrm{ShDM}+$ $\mathrm{RDM}$ ) were determined, as well as the following ratios (Benincasa 2003): root-shoot $(\mathrm{RShR}=\mathrm{RDM} /$ ShDM); specific leaf area (SLA $=$ LA/LDM); leaf area $(\mathrm{LAR}=\mathrm{LA} / \mathrm{PDM})$; leaf mass $(\mathrm{LMR}=\mathrm{LDM} /$ $\mathrm{PDM})$; stem mass $(\mathrm{SMR}=\mathrm{SDM} / \mathrm{PDM})$; and root mass $(\mathrm{RMR}=\mathrm{RDM} / \mathrm{PDM})$.

The temperatures and relative humidity of the air inside the greenhouse were daily measured with a digital thermohygrometer. During plant growth, the environmental conditions inside the greenhouse were characterized by air temperature between $5.5^{\circ} \mathrm{C}$ and $21.0^{\circ} \mathrm{C}$ (minimum) and between $26.7^{\circ} \mathrm{C}$ and $47.8{ }^{\circ} \mathrm{C}$ (maximum), and air relative humidity between $13 \%$ and $76 \%$ (minimum) and between $79 \%$ and $99 \%$ (maximum). The results were submitted to the analysis of variance by the $F$ test and to the polynomial regression analysis up to the second grade. In both analyses, the biological responses were interpreted with p-values of $1 \%$ and $5 \%$.

\section{RESULTS AND DISCUSSION}

The mean volume per pot (MVP) applied in each irrigation stage (Table 2) increased with decreasing matric potentials. Thus, the irrigation interval (MII) increased more than proportionally with the increase of MVP, while the number of irrigations (NI) and the total volume applied (MTVP), as a consequence, decreased more than proportionally with MII increases. This is in accordance with the physical principles of water movement in the soil, since under conditions of non-saturation, decrements in water content reduce exponentially soil hydraulic conductivity (Reichardt \& Timm 2004) and this reduces the radial flow of water from a point of the soil to the root-soil interface. Thus, this results in a gradual reduction of water uptake by roots from the
Table 2. Mean volume of water applied per pot (MVP), mean interval between irrigations (MII), number of irrigations (NI) and mean total volume of water applied per pot (MTVP) from 21 to 140 days after transplanting (Uberlândia, Minas Gerais State, Brazil, 2010).

\begin{tabular}{cccccc}
\hline Treatments & MVP & MII & \multirow{2}{*}{ NI } & MTVP \\
\cline { 1 - 2 } $\mathrm{kPa}$ & $\mathrm{L}$ & days & & & $\mathrm{L}$ \\
\hline-10 & 0.946 & 2.03 & & 59 & 55.80 \\
-30 & 1.381 & 4.29 & & 28 & 38.67 \\
-50 & 1.447 & 5.22 & & 23 & 33.28 \\
-70 & 1.485 & 8.00 & & 15 & 22.28 \\
\hline
\end{tabular}

soil, increasing the time for the defined lower limit of matric potential to be reached.

In this experiment, decreasing the matric potential in the substrate, starting from $-10 \mathrm{kPa}$, negatively affected the dry mass accumulation in all plant parts $(\mathrm{p}<0.01$; Figure 1$)$. Therefore, the difficulty of "Ora-pro-nobis" plants to absorb water from the substrate increased gradually with each unit of matric potential reduction, resulting in signs of water deficit stress such as reduced growth. Similar results were obtained in many experiments, with forestry species, flowers and cactus (Figueirôa et al. 2004, Snyman 2004, Álvarez et al. 2009, Silva et al. 2010, Martins et al. 2010).

In leaves and stems, reductions were linear, with stems showing higher rates $\left(1.19 \mathrm{~g} \mathrm{kPa}^{-1}\right)$ than those observed in leaves $\left(0.19 \mathrm{~g} \mathrm{kPa}^{-1}\right)$. In roots, the reductions occurred according to a quadratic model, more accentuated from $-10 \mathrm{kPa}$ to $-30 \mathrm{kPa}$ than from $-30 \mathrm{kPa}$ to $-50 \mathrm{kPa}$, while from $-50 \mathrm{kPa}$ to $-70 \mathrm{kPa}$

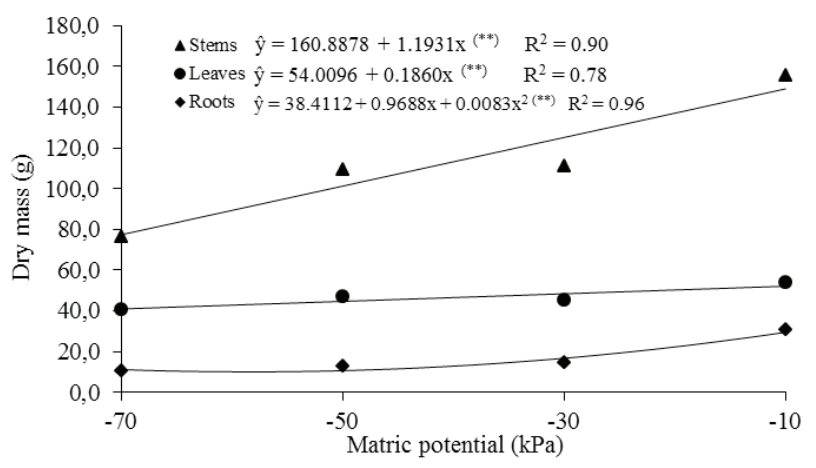

Figure 1. Accumulated dry mass in leaves, stems and roots of "Ora-pro-nobis" plants, regression equations $(\hat{y})$ and determination coefficients $\left(\mathrm{R}^{2}\right)$ at 120 days after the start of treatments (Uberlândia, Minas Gerais State, Brazil, 2010). ${ }^{(*)}$ Significant at $1 \%$. 
practically no reduction was detected (Figure 1). Significant reductions in the dry mass of leaves, stems and roots, due to increasing soil water deficits, were also reported in other plant species (Figueirôa et al. 2004, Liu \& Stützel 2004, Bonfim-Silva et al. 2011), including two Cactaceae species of the Opuntia genus (Snyman 2004).

The lower availability of water in the substrate caused by the reductions in the matric potential may cause a decrease in $\mathrm{CO}_{2}$ absorption by the plant and, consequently, a reduction in photosynthesis and in the amount of accumulated dry mass. The absorption of $\mathrm{CO}_{2}$ by plants occurs through stomatal pores that tend to close under conditions of high temperature, low water availability in the soil or high transpiration rate, and these facts may adversely affect biomass accumulation due to photosynthesis reduction (Yordanov et al. 2003, Shao et al. 2008, Tardieu et al. 2011).

These results give support to the statement that plants of the Pereskia genus, despite belonging to the Cactaceae family, respond positively to increasing levels of water availability in the root zone (Leuenberger 1992). This sensitivity had been already evidenced by McConnell \& Host (1980), in Pereskia aculeata Godseffiana plants. These plants, when irrigated once a week, increased significantly more in height and number of leaves than when irrigated every two to three weeks.

The dry mass accumulated in leaves decreased proportionally less than in stems and roots, since dry mass ratios of leaves and stems (LSR) and leaves and roots (LRR) increased linearly with the decrease in the substrate matric potential (Figure 2). When stems and roots (SRR; Figure 2) are analyzed, it is noted that the reduction in accumulated dry mass in stems was proportionally less than in roots, in agreement with a quadratic model, from $-10 \mathrm{kPa}$ to $-53 \mathrm{kPa}$ (maximum point in the quadratic equation), but at gradually decreasing rates. From $-53 \mathrm{kPa}$ to $-70 \mathrm{kPa}$, the dry mass accumulated in the stems reduced proportionately more than in roots, at gradually increasing rates.

Regarding the ratios between the dry mass in each plant organ and the total dry biomass, leaves mass ratio (LMR) increased linearly with matric potential reductions $(\mathrm{p}<0,01)$ at an estimated rate of $0.0015 \mathrm{~g} \mathrm{~g} \mathrm{~g}^{-1} \mathrm{kPa}^{-1}$ (Figure 3). Therefore, with decreasing matric potentials, the photoassimilates translocation from leaves to stems and roots also decreased. According to Benincasa (2003), LMR is an estimate of the first phase of dry mass translocation from leaves to the other plant parts.

At 120 days after the start of treatments, $23 \%$ of plant dry mass were accumulated in leaves at $-10 \mathrm{kPa}$, while at $-30 \mathrm{kPa},-50 \mathrm{kPa}$ and $-70 \mathrm{kPa}$ that value was $25 \%, 28 \%$ and $32 \%$, respectively. Vilela \& Büll (1999) also observed a proportionally greater retention of dry mass in leaves under more pronounced soil water deficits. This is an interesting result for an edible plant, because even at relative small availability of water, proportionally more mass is accumulated in the edible organ (leaves).

The behavior of the stems dry mass ratio (SMR) followed a quadratic model, but with only

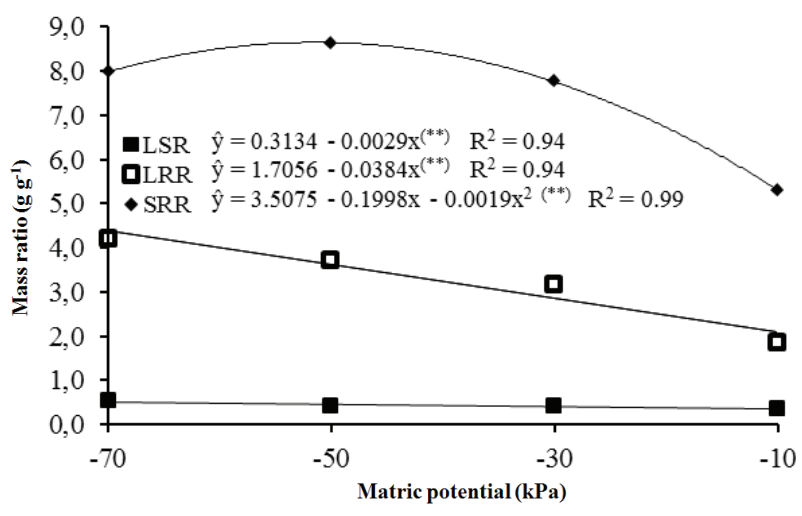

Figure 2. Dry mass ratios, regression equations $(\hat{\mathrm{y}})$ and determination coefficients $\left(\mathrm{R}^{2}\right)$ for leaves and stems (LSR), leaves and roots (LRR) and stems and roots (SRR) of "Ora-pro-nobis" plants (Uberlândia, Minas Gerais State, Brazil, 2010). ${ }^{(* *)}$ Significant at $1 \%$.

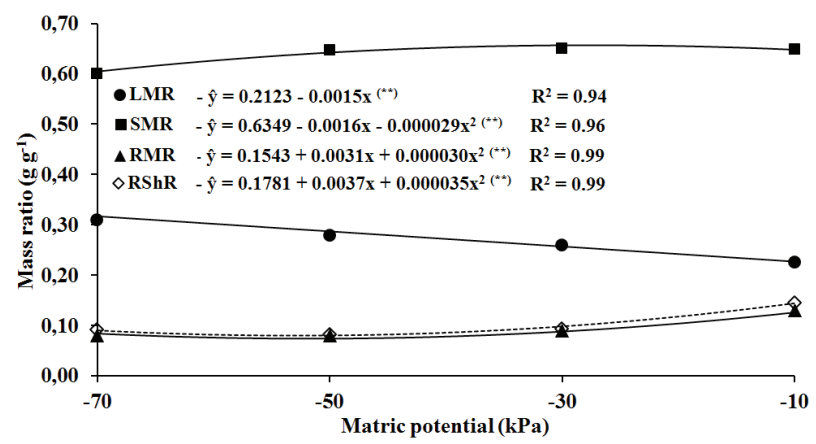

Figure 3. Dry mass ratio in "Ora-pro-nobis" plants, regression equations $(\hat{y})$ and determination coefficients $\left(R^{2}\right)$ for leaves and total plant (LMR), stems and total plant (SMR), roots and total plant (RMR) and root and shoot (RShR) at 120 days after the start of treatments (Uberlândia, Minas Gerais State, Brazil, 2010). ${ }^{(* *)}$ Significant at $1 \%$. 
$6.1 \%$ of maximum variation. The proportion of dry mass accumulated in stems increased to 64.6- 65.8 \% of plant dry mass from $-10 \mathrm{kPa}$ to $-30 \mathrm{kPa}$, decreased again to $64.6 \%$ at $-50 \mathrm{kPa}$ and reached $59.7 \%$ at $-70 \mathrm{kPa}$. This behavior shows that SMR was negatively affected with a slightly higher severity from $-50 \mathrm{kPa}$ to $-70 \mathrm{kPa}$ than from $-10 \mathrm{kPa}$ to $-50 \mathrm{kPa}$.

The ratios between root and shoot (RShR) and root and whole plant (RMR), according to a quadratic model, decreased progressively less from $-10 \mathrm{kPa}$ to $-50 \mathrm{kPa}$, with values of $14.7 \%$ and $12.8 \%$ at $-10 \mathrm{kPa}, 9.7 \%$ and $8.8 \%$ at $-30 \mathrm{kPa}$ and $7.4 \%$ and $6.8 \%$ at $-50 \mathrm{kPa}$. From $-50 \mathrm{kPa}$ to $-70 \mathrm{kPa}$, the proportion of root dry mass increased to $9.5 \%$ and $8.7 \%$, respectively for RShR and RMR.

The joint analysis of such mass ratios seems to indicate that increments in the soil water deficits brought about modifications in the mass allocation among plant organs. The proportion of dry mass in leaves increased linearly, whereas the relative proportion of dry mass of stems remained approximately constant from $-10 \mathrm{kPa}$ to $-50 \mathrm{kPa}$ and decreased slightly more pronouncedly from $-50 \mathrm{kPa}$ to $-70 \mathrm{kPa}$. The roots dry mass ratio was proportionally more affected from $-10 \mathrm{kPa}$ to $-50 \mathrm{kPa}$ and was near stable between $-50 \mathrm{kPa}$ and $-70 \mathrm{kPa}$.

These results are similar to those reported by Silva \& Nogueira (2003), in three species of woody plants (Prosopis juliflora, Mimosa caesalpiniifolia and Tabebuia aurea) grown under greenhouse conditions. Under water deficit conditions, these species allocated more dry mass to the shoot than to the roots. However, a fourth woody species (Enterolobium contortisiliquum) showed an inverse behavior, as observed by Correia \& Nogueira (2006), in peanut (Arachis hypogaea). These results show that plant response to water deficit is a speciesdependent trait. According to Chaves et al. (2002), the extent of the influence of water deficit is related to its intensity and duration and also to the plant genetic capacity to respond to environmental stimuli.

Although the leaves dry mass showed linear reductions (Figure 1), the water deficit intensity caused by matric potential reduction from $-10 \mathrm{kPa}$ to $-70 \mathrm{kPa}$ was not severe enough to reduce the plant leaf area ( $p>0.05$; Figure 4). Thus, the specific leaf area (SLA) also increased linearly at an estimated rate of $0.63 \mathrm{~cm}^{2} \mathrm{~g}^{-1} \mathrm{kPa}^{-1}$ (Figure 4). According to Benincasa (2003), an increase in the SLA means that leaf thickness was reduced.

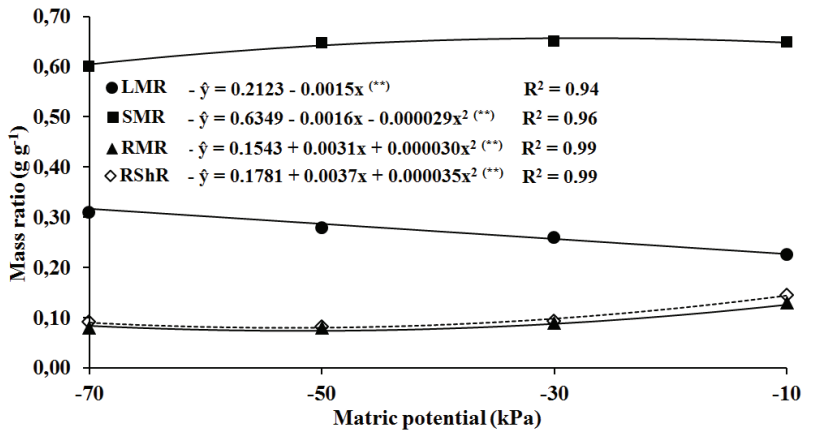

Figure 4. Leaf area (LA), leaf area ratio (LAR) and specific leaf area (SLA) in "Ora-pro-nobis" plants, regression equations $(\hat{y})$ and determination coefficients $\left(R^{2}\right)$ at 120 days after the start of treatments (Uberlândia, Minas Gerais State, Brazil, 2010). ${ }^{(\mathrm{NS})}$ and ${ }^{(* *)}$ : not significant at $5 \%$ and significant at $1 \%$, by the $\mathrm{F}$ test, respectively.

Although in completely developed leaves water deficits may cause leaf senescence and abscission (Lim et al. 2007), in this study, from 21 to 140 days after transplanting, no leaf drop was observed in any plant of any treatment. This reinforces the assumption made earlier about the influence of water stress on leaf area. The reduction in the substrate matric potential, within the range studied in this experiment, resulted in a water stress evidenced only by the reduction in plant biomass, but not directly by leaf drop and/or decrease in the leaves area.

The leaf area ratio (LAR), which expresses the useful leaf area for photosynthesis (Benincasa 2003) or the ratio between the area responsible for interception of both light and carbon dioxide and the total plant dry mass (Silva \& Nogueira 2003), behaved in a similar way to the SLA ( $p<0.01$; Figure 4). This result demonstrates that, as the water deficit in the substrate increased with decreasing matric potential, "Ora-pro-nobis" leaves were less efficient in accumulating dry mass.

\section{CONCLUSIONS}

1. As leaf area was not affected and there was no leaf drop, it is possible to conclude that Pereskia aculeata is tolerant to drought stress.

2 . The reduction of matric potential in the root zone of "Ora-pro-nobis" plants, even intermittently, between $-10 \mathrm{kPa}$ and $-70 \mathrm{kPa}$, affect dry mass accumulation in leaves less than in stems and 
roots. This is interesting, since leaves are the main commercial product of this plant.

3. Drought reduces the photosynthetic efficiency of Pereskia aculeata leaves by increasing specific leaf area and leaf area ratio, although not affecting directly leaf area.

\section{ACKNOWLEDGMENTS}

We are grateful to Professor José C. Barbosa (Universidade Estadual Paulista "Júlio de Mesquita Filho" - Unesp) by helping us with the statistical analysis; Professor Carlos M. M. Queiroz (Instituto Federal do Triângulo Mineiro - IFTM) by leaf images processing; Jéssica P. dos Santos and Cristina M. dos S. Moraes by collaborating with the data collection; Coordenação de Aperfeiçoamento de Pessoal de Nível Superior (Capes) and IFTM for funding and supporting the conduction of the experiment.

\section{REFERENCES}

ABRAMOFF, M. D. et al. Image processing with ImageJ. Biophotonics International, Pittsfield, v. 11, n. 7, p. 36-42, 2004.

ALMEIDA, M. E. F.; CORRÊA, A. D. Utilização de cactáceas do gênero Pereskia na alimentação humana em um município de Minas Gerais. Ciência Rural, Santa Maria, v. 42, n. 4, p. 751-756, 2012.

ÁLVAREZ, S. et al. Regulated deficit irrigation in potted dianthus plants: effects of severe and moderate water stress on growth and physiological responses. Scientia Horticulturae, Amsterdam, v. 122, n. 4, p. 579-585, 2009.

BENINCASA, M. M. P. Análise de crescimento de plantas: noções básicas. Jaboticabal: Funep, 2003.

BONFIM-SILVA, E. M. et al. Desenvolvimento inicial de gramíneas submetidas ao estresse hídrico. Revista Caatinga, Mossoró, v. 24, n. 2, p. 180-186, 2011.

BRASIL. Ministério da Agricultura, Pecuária e Abastecimento. Manual de hortaliças nãoconvencionais. Brasília, DF: MAPA, 2010.

BRITO, A. dos S. et al. Desempenho do tensiômetro com diferentes sistemas de leitura. Revista Brasileira de Ciência do Solo, Viçosa, v. 33, n. 2, p. 17-24, 2009.
CHAVES, M. M. et al. How plants cope with water stress in field: photosynthesis and growth. Annals of Botanny, Oxford, v. 89, n. 7, p. 907-916, 2002.

COELHO, E. F. et al. Sensor placement for soil water monitoring in lemon irrigated by micro sprinkler. Revista Brasileira de Engenharia Agrícola e Ambiental, Campina Grande, v. 11, n. 1, p. 46-52, 2007.

CORREIA, K. G.; NOGUEIRA, R. J. M. C. Avaliação do crescimento do amendoim (Arachis hupogaea L.) submetido a déficit hídrico. Revista de Biologia e Ciências da Terra, Campina Grande, v. 4, n. 2, p. 1-7, 2006.

DUARTE, M. R.; HAYASHI, S. S. Estudo anatômico de folha e caule de Pereskia aculeata Mill. (Cactaceae). Revista Brasileira de Farmacognosia, Curitiba, v. 15, n. 2, p. 103-109, 2005.

FIGUEIRÔA, J. M. et al. Crescimento de plantas jovens de Myracrodruon urundeuva Allemão (Anacardiaceae) sob diferentes regimes hídricos. Acta Botanica Brasilica, Feira de Santana, v. 18, n. 3, p. 573-580, 2004.

GENUCHTEN, M. T. V. A closed form equation for predicting the hydraulic conductivity of unsaturated soils. Soil Science Society of America Journal, Washington, DC, v. 44, n. 5, p. 892-898, 1980.

KROON, H. D. et al. A modular concept of phenotypic plasticity in plants. New Phytologist, Lancaster, v. 166, n. 1, p. 73-82, 2005.

KOZLOWSKI, T. T.; PALLARDI, S. G. Acclimation and adaptive responses of woody plants to environmental stresses. The Botanical Review, New York, v. 68, n. 2, p. 270-334, 2002.

LEUENBERGER, B. E. Leaf-bearing cacti (genus Pereskia) in cultivation. Cactus and Succulent Journal, Claremont, v. 64, n. 5, p. 247-261, 1992.

LIM, P. O. et al. Leaf senescence. Annual Review of Plant Biology, Palo Alto, v. 58, n. 1, p. 115-136, 2007.

LIMA JÚNIOR, J. A. et al. Desempenho de cultivares de cenoura em função da água no solo. Revista Brasileira de Engenharia Agrícola e Ambiental, Campina Grande, v. 16, n. 5, p. 514-520, 2012.

LIU, F.; STÜTZEL, H. Biomass partitioning, specific leaf area and water use efficiency of vegetable amaranth (Amaranthus spp.) in response to drought 
stress. Horticultural Science, Prague, v. 102, n. 1, p. 15-27, 2004.

LOPES, A. S. et al. Manejo da irrigação (tensiometria e balanço hídrico climatológico) para a cultura do feijoeiro em sistemas de cultivo direto e convencional. Engenharia Agrícola, Jaboticabal, v. 24, n. 1, p. 89-100, 2004.

MARTINS, M. de O. et al. Crescimento de plantas jovens de nin-indiano (Azadirachta indica A. Juss Meliaceae) sob diferentes regimes hídricos. Revista Árvore, Viçosa, v. 34, n. 5, p. 771-779, 2010.

McCONNELL, D. B.; HOST, J. Influence of watering frequency on growth and anatomy of lemon vine. Proceedings of the Florida State Horticultural Society, Gainesville, v. 93, n. 1, p. 164-165, 1980.

NEUMANN, P. M. Coping mechanisms for crop plants in drought-prone environments. Annals of Botany, Oxford, v. 101, n. 7, p. 901-907, 2008.

REICHARDT, K.; TIMM, L. C. Os processos. In: REICHARDT, K.; TIMM, L. C. Solo, planta e atmosfera: conceitos, processos e aplicações. Barueri: Manole, 2004. p. 87-145.

SHAO, H. B. et al. Water-deficit stress-induced anatomical changes in higher plants. Comptes Rendus Biologies, Paris, v. 331, n. 3, p. 215-225, 2008.

SILVA, E. C. da et al. Growth evaluation and water relations of Erythrina velutina seedlings in response to drought stress. Brazilian Society of Plant Physiology, Campos dos Goytacazes, v. 22, n. 4, p. 225-233, 2010.

SILVA, E. C. da et al. Water relations and organic solutes production in four umbu tree (Spondias tuberosa) genotypes under intermittent drought. Brazilian Society of Plant Physiology, Campos dos Goytacazes, v. 21, n. 1, p. 43-53, 2009.

SILVA, E. C.; NOGUEIRA, R. J. M. C. Crescimento de quatro espécies lenhosas cultivadas sob estresse hídrico em casa-de-vegetação. Revista Ceres, Viçosa, v. 50, n. 288, p. 203-217, 2003.

SKIRYCZ, A.; INZÉ, D. More from less: plant growth under limited water. Current Opinion in Biotechnology, London, v. 21, n. 2, p. 197-203, 2010.

SNYMAN, H. A. Effect of various water applications strategies on root development of Opuntia ficusindica and $O$. robusta under greenhouse growth conditions. Journal of the Professional Association for Cactus Development, Chapingo, v. 6, n. 1, p. 3560, 2004.

STOLF, R. et al. Morpho-anatomical and micromorphometrical evaluations in soybean genotypes during water stress. Brazilian Archives of Biology and Technology, Curitiba, v. 52, n. 6, p. 1321-1331, 2009.

TAKEIT, C. Y. et al. Nutritive evaluation of a nonconvencional leafy vegetable (Pereskia aculeata Miller). International Journal of Food Sciences and Nutrition, London, v. 60, n. 1, p. 148-160, 2009.

TARDIEU, F. et al. Water deficit and growth: coordinating processes without an orchestrator? Current Opinion in Plant Biology, London, v. 14, n. 3, p. 283289, 2011.

TOFFANELI, M. B. D.; RESENDE, S. G. Sistemas de condução na produção de folhas de ora-pro-nobis. Pesquisa Agropecuária Tropical, Goiânia, v. 41, n. 3, p. 466-143, 2011.

VILAS BOAS, R. C. et al. Desempenho de cultivares de cebola em função do manejo da irrigação por gotejamento. Revista Brasileira de Engenharia Agrícola e Ambiental, Campina Grande, v. 15, n. 2, p. 117-124, 2011.

VILELA, E. F.; BÜLL, L. T. Avaliação do crescimento de plantas de milho em função de doses de potássio e estresse hídrico. Revista Brasileira de Ciência do Solo, Viçosa, v. 23, n. 2, p. 281-289, 1999.

YIN, C. et al. Early growth, dry matter allocation and water use efficiency of two sympatric Populus species as affected by water stress. Environmental and Experimental Botany, Elmsford, v. 53, n. 3, p. 315-322, 2005.

YORDANOV, I. et al. Plant responses to drought and stress tolerance. Bulgarian Journal of Plant Physiology, Sofia, v. 29, n. 3-4, p. 187-206, 2003. 